\title{
Article \\ Effect of Sowing Date on Soybean Development in South-Western Poland
}

\author{
Magdalena Serafin-Andrzejewska ${ }^{1, * \mathbb{D}}$, Waldemar Helios ${ }^{1} \mathbb{D}$, Anna Jama-Rodzeńska ${ }^{1} \mathbb{D}$, Marcin Kozak $^{1}$, \\ Andrzej Kotecki ${ }^{1}$ and Leszek Kuchar ${ }^{2}$
}

1 Institute of Agroecology and Plant Production, Wrocław University of Environmental and Life Sciences, 24A Grunwaldzki Square, 50-363 Wrocław, Poland; waldemar.helios@upwr.edu.pl (W.H.); anna.jama@upwr.edu.pl (A.J.-R.); marcin.kozak@upwr.edu.pl (M.K.); andrzej.kotecki@upwr.edu.pl (A.K.)

2 Department of Applied Mathematics, Wrocław University of Environmental and Life Sciences, Grunwaldzka St. 53, 50-357 Wrocław, Poland; leszek.kuchar@upwr.edu.pl

* Correspondence: magdalena.serafin-andrzejewska@upwr.edu.pl

Citation: Serafin-Andrzejewska, M.; Helios, W.; Jama-Rodzeńska, A.; Kozak, M.; Kotecki, A.; Kuchar, L. Effect of Sowing Date on Soybean Development in South-Western

Poland. Agriculture 2021, 11, 413. https://doi.org/10.3390/agriculture 11050413

Received: 26 March 2021

Accepted: 27 April 2021

Published: 3 May 2021

Publisher's Note: MDPI stays neutral with regard to jurisdictional claims in published maps and institutional affiliations.

Copyright: (c) 2021 by the authors. Licensee MDPI, Basel, Switzerland. This article is an open access article distributed under the terms and conditions of the Creative Commons Attribution (CC BY) license (https:// creativecommons.org/licenses/by/ $4.0 /)$.

\begin{abstract}
Soybean is a thermophilic and photophilic plant very sensitive to weather course during the vegetation period. This trait limits soybean cultivation in higher latitude countries. This field study aimed to evaluate the effects of three sowing dates on the development, the duration of vegetative and generative stages, and the yield of two soybean cultivars (Lissabon and Merlin) under conditions in south-western Poland in the years 2016-2019. The sowing date determines the temperature and the day length available for soybean plants, influencing development and yield. Delaying the sowing date by 20 days in relation to the earliest (16-21.04) resulted in the shortening of the length of the vegetative development by 12 days and the shortening of the entire vegetation period by 14 days. The delayed sowing date (06-19.05) under the conditions of south-western Poland (Lower Silesia) contributed to a significant decrease in yield. Lissabon produced greater soybean yield than Merlin. Special attention should be paid to proper seed sowing dates in soybean agriculture practice. It is necessary to breed soybean genotypes adapted to day length and thermal conditions of the cultivation area to achieve the maximum seed yield.
\end{abstract}

Keywords: soybean; sowing date; yield; day length; temperature; development; vegetation period; vegetative and generative stage

\section{Introduction}

Soybean is a strategically nutritious plant. In the case of the cultivation area, it ranks fourth in the world, behind wheat, maize, and rice. At the same time, it is the main noncereal cultivated plant. Soybean cultivation area in 2019 reached 120.5 million ha in 95 countries [1]. Soybean seed production is dominated by the USA, Brazil, Argentina, India, China, Paraguay, Canada, and Ukraine, where about $92 \%$ of the soybean world area is located. In the remaining 86 countries of the world, the soybean cultivation area does not exceed $8 \%$, and production is lower than $6 \%$.

In Poland, soybean has been cultivated for about 140 years, but the first significant milestones in soybean cultivation followed in the second decade of the 21st century. The main factor limiting an increase in soybean cultivation in Poland is the small progress in breeding new varieties adapted to the climatic conditions of central-eastern Europe.

According to American studies, the success of soybean cultivation depends on the course of thermal and humidity conditions during vegetation [2,3]; among them, the most important are temperature and photoperiodism and their interactions $[4,5]$. Temperature is closely related to the metabolism of plants, i.e., their growth speed, as well as the chronological duration of subsequent development phases. Temperature combined with photoperiodism initiates the flowering phase [6,7]. It was shown that photoperiod and 
temperature interact with the genotype to control soybean growth and development throughout the growing season $[8,9]$.

Soybean is an economically important legume plant that can be used in the feed industry as defatted, toasted soybean meals, and in livestock nutrition [10,11]. Its high nutritional value relates to amino acid composition, high digestibility due to low fiber content, and high protein and fat content (an average of $40 \%$ and about $20 \%$ of the seed dry weight, respectively) [10]. Poland is the largest poultry producer in the European Union. According to Eurostat data [12], 70\% of poultry production in the EU came from six Member States, most of them from Poland (16.8\%). Additionally, cattle production in Poland constitutes an important section of agricultural production that provides $26 \%$ of gross agricultural output, therefore, the demand for protein feed should be satisfied and fulfilled [13]. In 2016, GM soybean meal covered $65 \%$ of the protein requirements for livestock feed in Poland. Soyabean meal is imported into the EU from genetically modified plants [14]. In addition, the EU has a relatively high demand for non-genetically modified (non-GM) soybeans compared to other parts of the world, and food/feed ingredients containing more than $0.9 \%$ GM material must be labeled.

Legumes cultivated in Poland cover only $11 \%$ of the fodder protein needs of livestock [13]. The most promising among legumes are soybean varieties with grains that are characterized with high protein content that would play an essential role in animal nutrition. Therefore, the cultivation of soybean is increasing in EU countries and in Poland [11].

In connection with the implementation of the nationwide program, "Center for Research on Protein Varieties Research Initiative", the area of cultivation, the yields of the tested soybean varieties, and the higher protein yield in Poland increased. The area with soybean cultivation in 2010 was 0.2 thousand hectares and in 2019 gained near 20 thousand hectares [15]. Varietal progress contributed to soybean cultivation across the whole of Poland, especially the acquisition of varieties with a shorter growing season (around 120-130 days). Poland is located close to the northern limit of soyabean cultivation, therefore, Polish varieties characterize with different climate-specific traits, for example, tolerance to long periods of daylight and tolerance to low temperatures. Polish varieties blossom and ripen earlier than, for example, Japanese varieties [16].

Early maturity is an important characteristic of soybeans, especially in regions where the growing season can be limited because of the short autumn period and early snowfall. The abscission of flowers and pods can be also regarded as a factor contributing to lower yields of soyabean [16].

The thermal requirements of soybeans and their response to the length of the day are the main factors limiting the possibilities of cultivating this plant in higher latitude countries. Poland is located between $49^{\circ}$ and $54^{\circ} \mathrm{N}$ latitude, and the climatic conditions are not favorable for the cultivation of this species. The main goal of the soybean domestication and the cultivar diversification process was genotype adaptation for a specific photoperiod [17]. Due to the climate warming, cultivation range of a such crop as soybean with high thermal conditions is moving north. More frequently, occurrence of periodic droughts and high temperatures is a limiting factor for plant cultivation, hence, the breeding of new varieties plays an important role. Breeding progress should be based on the development of varieties that are useful in Poland's diverse agroclimatic conditions and that can tolerate high soil moisture and lower temperatures and have a short vegetation period. In the mid1970s, research at scientific institutions in Poland developed the varieties characterized by a suitable earliness for Polish conditions, which had high yield and adapted to mechanical cultivation. The most favorable weather conditions for soybean cultivation in Poland are in Lower Silesia with continental characteristics of climate and longer vegetation period compared to the rest of the country [18].

The aim of the research was to determine the effect of sowing date on the length of soybean vegetation, the duration of individual development stages, and the impact of these relationships on the size of the seed yield. Adapting the sowing date to the localization of soybean cultivation and local weather conditions influence the thermal conditions and 
the day length during the vegetation period of soybeans. The sowing date is a non-input factor in cultivation technology, and it may turn out to be strategic in solving the problem of soybean yield in the climatic conditions of south-western Poland.

\section{Materials and Methods}

\subsection{Details of Field Experiment}

In the years 2016-2019, field experiments were conducted to evaluate the effect of sowing dates on growth, development, and yield of soybean cultivars. The experiments were conducted on the field of the Wrocław University of Environmental and Life Sciences $\left(51^{\circ} 10^{\prime} \mathrm{N}, 17^{\circ} 06^{\prime} \mathrm{E}\right)$ in the Lower Silesia, Wrocław, Poland (Figure 1).

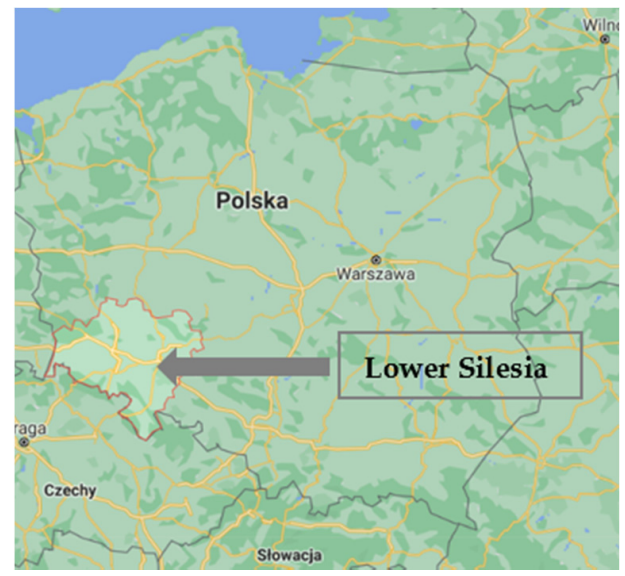

Figure 1. Field experiments site in Lower Silesia, south-western Poland.

The field experiment had a split-plot design. Sowing date (I-the earliest, II-delayed 10 days in relation to the earliest date, III-delayed 20 days in relation to the earliest) was allocated in the main plots, and the cultivars (Lissabon, Merlin) were placed in the sub-plots.

Detailed sowing dates and weather conditions in the study years are given in Table 1.

Table 1. Weather conditions and sowing dates of soybean in years 2016-2019-Wrocław 51 $11^{\prime} \mathrm{N}^{\prime} 17^{\circ} 06^{\prime} \mathrm{E}$ (southwestern Poland).

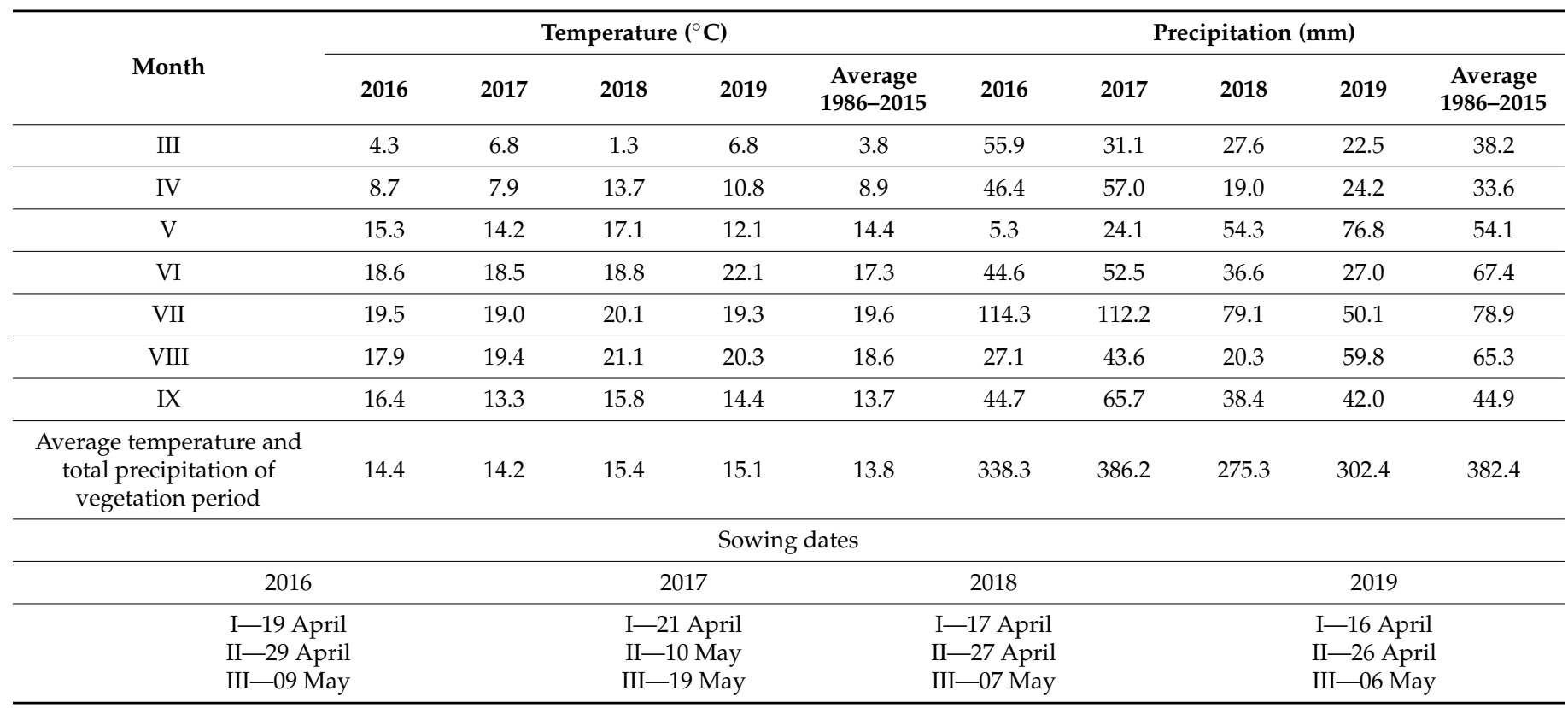


The area of a single sub-plot was $15 \mathrm{~m}^{2}(10 \mathrm{~m} \times 1.5 \mathrm{~m})$. The field experiment was set up on Cutanic Stagnic Luvisol $[19,20]$ i.e., the lessive-type soils with textural differentiation within soil profile (due to clay translocation) and seasonal oversaturation with stagnant water. In the years of the field experiment, the $\mathrm{pH}$ of soil ranged from 5.9-6.4, and the contents of macronutrients were as follows ( $\mathrm{mg} \mathrm{kg}^{-1}$ ): P 62.3-166.0, $\mathrm{K}$ 154.-234.0, $\mathrm{Mg}$ 75.7-101.0. In each year of study, the preceding crop was winter wheat. Before the establishment of the experiment, mineral fertilization was applied $\left(\mathrm{kg} \mathrm{ha}^{-1}\right)$ : $60 \mathrm{P}_{2} \mathrm{O}_{5}(46 \%$ triple superphosphate) and $120 \mathrm{~K}_{2} \mathrm{O}(60 \%$ sylvinite). Fertilizers were applied directly before sowing and were mechanically mixed with the soil to a depth of approximately $5 \mathrm{~cm}$. Soybeans were sown at a row spacing $15 \mathrm{~cm}$, and the number of sown seeds of good quality (good germination and purity) was 90 per $1 \mathrm{~m}^{2}$, according to the scheme of the experiment. Seeds of both cultivars were inoculated with Bradyrhizobium japonicum using the Fix Fertig Saatbau technology. Fix Fertig is a technological process in which seeds are coated with nitrogenfixing bacteria along with an adhesive that acts as a preservative. Such prepared seeds are ready for sowing. Every year, weeds were controlled on an identical schedule: directly after sowing, weed infestation was regulated with the herbicide Boxer $800 \mathrm{EC}\left(4.0 \mathrm{~L} \mathrm{ha}^{-1}\right.$, active substance: $800 \mathrm{~g} \mathrm{~L}^{-1}$ prosulfocarb; Syngenta Poland), monocotyledonous weeds were controlled with the herbicide Fusilade Forte $150 \mathrm{EC}\left(1.5 \mathrm{~L} \mathrm{ha}^{-1}\right.$, active substance: $150 \mathrm{~g} \mathrm{~L}^{-1}$ fluazifop-P-butyl; Syngenta Poland), and secondary weed infestation was limited by the herbicide Corum (1.25 $\mathrm{L} \mathrm{ha}^{-1}$, active substance: $480 \mathrm{~g} \mathrm{~L}^{-1}$ bentazone and $22.4 \mathrm{~g} \mathrm{~L}^{-1}$ imazamox; BASF) with the addition of Dash HC adjuvant (0.6 $\mathrm{L} \mathrm{ha}^{-1}$; BASF).

The harvest was carried out in 2016 in the first half of September, in 2017 in the end of September (first sowing date) and in mid-October (both delayed sowing dates), in 2018 in the beginning of September, and in 2019 in the first week of September, except Lissabon cultivar sown in the third (latest) date, which was harvested in third week of September, at the full maturity stage when $95 \%$ of the pods turned a mature pod color and when the seed had a low moisture content $(\leq 15 \%)$. Seed yield from the plots was converted into the yield per hectare taking into account $15 \%$ moisture.

\subsection{Data Collection}

Each year from sowing to full maturity (BBCH 89) of soybean plants, field observations were introduced. Field observations were carried out, depending on the needs, 2-3 times a week, with greater frequency in the period from sowing to the beginning of flowering. Growing stages in BBCH scale and the development of plants were noted [21]. Based on the number of days between growing stages, the length of the main growing stagesvegetative from sowing, vegetative from emergence, generative, and total vegetation period-was calculated.

The sum of day length $(\mathrm{h})$ for Wrocław latitude $\left(51^{\circ} 10^{\prime} \mathrm{N}\right)$ and the sum of average daily temperatures $\left({ }^{\circ} \mathrm{C}\right)$ for each year (2016-2019) were counted using data from a weather station situated near the experimental fields and belonging to the Institute of Agroecology and Plant Production Wrocław University of Environmental and Life Sciences (Poland).

\subsection{Data Analysis}

The development of soybean (mean for years, sowing dates, and cultivars), the length of mean soybean growth stages in days and in relative values (mean for sowing dates and cultivars for 2016-2019), the sum of day length, and the sum of average daily temperatures during soybean development and relative values (mean for sowing dates for 2016-2019) were calculated using Microsoft Excel. Moreover, all diagrams presented in this paper were created using Microsoft Excel (Microsoft Office 2010).

The analysis of variance (ANOVA) was done at the significance level $p<0.05$ using Statistica program 13.1 (StatSoft, Kraków, Poland). The experiment included three factors: four years, three sowing dates, two cultivars, and four randomized replicates arranged in a split-plot design. For the resulting data presented in the tables, standard deviations (SD) were calculated. Homogeneous groups were determined by Tukey's multiple range 
test using consecutive letters starting from " $\mathrm{a}$ "—-the most beneficial value—to " $\mathrm{j}$ "—least beneficial in terms of seed yields.

\section{Results and Discussion}

Both cultivars tested in the experiment are characterized by similar maturity, therefore, no differences in their development were observed as a result of delaying the sowing date. The length of the growing season and the lengths of the vegetative and the generative periods were most influenced by day length and air temperature, and the availability of these climatic factors for plants was determined by the sowing date. The highest number of days from sowing to maturity was observed in first sowing date. The highest differences (SD) in duration of development stages were noted in the end of the flowering stage $(\mathrm{BBCH}$ 69), especially in Lissabon cultivar in both delayed sowing dates (Table S1). Soybean is a photophilic and thermophilic plant. Most soybean cultivars are short-day plants. Accurately identifying the weather conditions that have the greatest impact on vegetative and generative development is an important step towards mitigating their impact on soybean yields, and adjusting the sowing time to the growing region can minimize the loss due to unfavorable weather conditions [22].

Delaying the sowing date by 20 days in relation to the earliest resulted in the shortening of the vegetation period by 14 days. In addition, a reduction of the time from emergence to the beginning of flowering by 7 days and the period from emergence to the end of vegetation by 9 days was observed. Between cultivars were slight differences noted. Vegetation periods were varied. The longest was the vegetation period in 2017, and the shortest (by 17 days) was in 2018. The highest differences were stated for means for cultivars in the cases of BBCH 69 and BBCH 89 in 2017 (Table 2). An earlier sowing date increased the use of light energy, because the plants began vegetation in the conditions of an extended day, and the generative development took longer, which allowed later varieties sowing. In Wisconsin, delaying the sowing date by a month resulted in shortening generative development by 15 days [23].

Table 2. Development of soybean (mean $\pm \mathrm{SD}$ for years, sowing dates, and cultivars)—Wrocław $51^{\circ} 10^{\prime} \mathrm{N}, 17^{\circ} 06^{\prime} \mathrm{E}$ (south-western Poland).

\begin{tabular}{|c|c|c|c|c|c|c|c|c|c|}
\hline \multirow{3}{*}{$\begin{array}{l}\text { Growing Stage } \\
\text { in Scale BBCH }\end{array}$} & \multicolumn{4}{|c|}{ Year } & \multicolumn{3}{|c|}{ Sowing Date } & \multicolumn{2}{|c|}{ Cultivar } \\
\hline & 2016 & 2017 & 2018 & 2019 & $\mathbf{I}$ & II & III & Lissabon & Merlin \\
\hline & \multicolumn{9}{|c|}{ Number of Days from Sowing to: } \\
\hline Emergence 10 & $15 \pm 2.2$ & $16 \pm 6.2$ & $11 \pm 2.1$ & $24 \pm 5.3$ & $20 \pm 7.6$ & $15 \pm 5.9$ & $15 \pm 2.1$ & $17 \pm 6.6$ & $16 \pm 6.0$ \\
\hline Flower buds on main stem 51 & $43 \pm 5.5$ & $48 \pm 7.8$ & $40 \pm 4.4$ & $49 \pm 5.0$ & $52 \pm 5.9$ & $45 \pm 4.5$ & $40 \pm 3.8$ & $46 \pm 6.6$ & $45 \pm 7.2$ \\
\hline Beginning of flowering 61 & $49 \pm 4.1$ & $52 \pm 7.8$ & $44 \pm 4.8$ & $52 \pm 5.9$ & $56 \pm 5.1$ & $48 \pm 3.2$ & $44 \pm 3.1$ & $50 \pm 6.5$ & $49 \pm 6.3$ \\
\hline End of flowering 69 & $85 \pm 5.2$ & $75 \pm 8.8$ & $60 \pm 5.7$ & $80 \pm 5.2$ & $82 \pm 9.8$ & $74 \pm 10.2$ & $69 \pm 10.4$ & $76 \pm 11.3$ & $74 \pm 11.2$ \\
\hline Maturity 89 & $128 \pm 4.5$ & $141 \pm 7.7$ & $124 \pm 12.1$ & $125 \pm 5.9$ & $138 \pm 8.2$ & $129 \pm 6.2$ & $124 \pm 9.6$ & $132 \pm 10.5$ & $130 \pm 10.5$ \\
\hline
\end{tabular}

Sowing dates: I-the earliest (16-21.04), II—delayed 10 days in relation to the earliest date (26.04-10.05), III—delayed 20 days in relation to the earliest (06-19.05).

The vegetative period from emergence and the entire vegetation period from emergence were the shortest in the latest sowing date (by 7 and 9 days, respectively). Soybean sowing in the latest date resulted in a change of the length of the development stages and a shift of four percentage points at the expense of vegetative development in favor of generative development in the total vegetation period (Table 3). Chen and Wiatrak (2010) [24] showed that, in conditions of Maryland (USA), the length of vegetation period shortened with later planting dates, and the shortening was greater for vegetative stages compared with generative stages. Their results suggest that May sowing dates would support greater yield potential for all maturity groups by extending duration of development stages. The shortening of soybean vegetation period by an average of 17 days due to the delayed sowing date in the climatic conditions of eastern Poland was indicated by Jarecki and Bobrecka-Jamro [25], which is consistent with the presented results. 
Table 3. Length of mean soybean growth stages in days and in relative values (\%) (mean for sowing dates and cultivars for 2016-2019)—Wrocław $51^{\circ} 10^{\prime}$ N, $17^{\circ} 06^{\prime}$ E (south-western Poland).

\begin{tabular}{|c|c|c|c|c|c|}
\hline \multirow{3}{*}{ Development } & \multicolumn{3}{|c|}{ Sowing Date } & \multicolumn{2}{|c|}{ Cultivars } \\
\hline & $\mathbf{I}$ & II & III & Lissabon & Merlin \\
\hline & \multicolumn{5}{|c|}{ Number of Days } \\
\hline Vegetative from emergence & 32 & 30 & 25 & 29 & 29 \\
\hline Generative & 86 & 84 & 84 & 86 & 85 \\
\hline \multirow[t]{2}{*}{ Vegetation period from emergence } & 118 & 114 & 109 & 115 & 114 \\
\hline & \multicolumn{5}{|c|}{ Relative values [\%] } \\
\hline Vegetative from emergence & 27 & 26 & 23 & 25 & 25 \\
\hline Generative & 73 & 74 & 77 & 75 & 75 \\
\hline
\end{tabular}

Sowing dates: I-the earliest (16-21.04), II—delayed 10 days in relation to the earliest date (26.04-10.05), III—delayed 20 days in relation to the earliest (06-19.05). Vegetative from emergence, development since emergence to the beginning of flowering; vegetation period from emergence, development since emergence to full maturity of seeds. Relative values (\%) show fraction of days in vegetative and generative periods from emergence to full maturity of soybean seeds.

Based on field observations, it was found that soybean plants developing under delayed sowing conditions were physiologically mature to enter the generative development stage, however, the shortened time of vegetative development meant that they were not properly formed. A properly selected sowing date determines the availability of light and temperature during the growth and the development of soybean plants and determines the correct course of phenological phases. It influences the proper development of vegetative and generative organs [26,27]. Air temperature may affect germination, growth, and flowering of the plant as well as the biochemical reactions taking place in it [28], shaping the course and the duration of all phenological phases of the plant [29]. The sums of the day length and the sum of the mean daily temperatures during vegetative and generative development of soybeans depending on the sowing date are presented in Table 4.

Table 4. Sum of day length $(\mathrm{h})$ and the sum of mean daily temperature $\left({ }^{\circ} \mathrm{C}\right)$ during soybean development and in relative values (\%) (mean for sowing dates for 2016-2019)—Wrocław $51^{\circ} 10^{\prime} \mathrm{N}, 17^{\circ} 06^{\prime} \mathrm{E}$ (south-western Poland).

\begin{tabular}{|c|c|c|c|}
\hline \multirow{3}{*}{ Development } & \multicolumn{3}{|c|}{ Sowing Date } \\
\hline & $\mathbf{I}$ & II & III \\
\hline & \multicolumn{3}{|c|}{ The Sum of Day Length [h] } \\
\hline Vegetative from emergence & 533.13 & 500.05 & 437.45 \\
\hline Generative & 1327.82 & 1295.92 & 1274.03 \\
\hline \multirow[t]{2}{*}{ Vegetation period from emergence } & 1860.95 & 1795.97 & 1711.48 \\
\hline & \multicolumn{3}{|c|}{ Relative values (\%) } \\
\hline Vegetative form emergence & 29 & 28 & 26 \\
\hline \multirow[t]{2}{*}{ Generative } & 71 & 72 & 74 \\
\hline & \multicolumn{3}{|c|}{ The sum of mean daily temperatures $\left({ }^{\circ} \mathrm{C}\right)$} \\
\hline Vegetative from emergence & 573.30 & 555.58 & 509.90 \\
\hline Generative & 1649.85 & 1616.28 & 1602.10 \\
\hline \multirow[t]{2}{*}{ Vegetation period from emergence } & 2223.15 & 2171.86 & 2112.00 \\
\hline & \multicolumn{3}{|c|}{ Relative values (\%) } \\
\hline Vegetative from emergence & 26 & 26 & 24 \\
\hline Generative & 74 & 74 & 76 \\
\hline
\end{tabular}

Sowing dates: I-the earliest (16-21.04), II—delayed 10 days in relation to the earliest date (26.04-10.05), III-delayed 20 days in relation to the earliest (06-19.05). Vegetative from emergence, development since emergence to the beginning of flowering; vegetation period from emergence, development since emergence to full maturity of seeds. Relative values (\%) show fraction of total days length (h) or daily temperature sum $\left({ }^{\circ} \mathrm{C}\right)$ within the vegetative and generative periods from emergence to full maturity of soybean.

Delaying the sowing date by 20 days in relation to the earliest caused a decrease in the total day length during vegetative development and the entire vegetation period by 18 and $8 \%$, respectively (Figure S1), which resulted in an average increase in day length during 
vegetative development by $0.84 \mathrm{~h}$ and a decrease in the day length during generative development by $0.27 \mathrm{~h}$ (Figure S2).

The delay in sowing soybean also influenced the changes in the total average daily temperature during the main development stages. The delay in sowing by 20 days in relation to the earliest resulted in a decrease in the total average daily temperature during the vegetative development by $11 \%$ and during the entire vegetation period by $5 \%$ (Figure S3), which resulted in an increase in the average daily temperature during vegetative development by $2.48{ }^{\circ} \mathrm{C}$ and a decrease in average daily temperatures during generative development by $0.11^{\circ} \mathrm{C}$ (Figure S4).

The period from emergence to the beginning of flowering in conditions of delayed sowing date was also shortened by $22 \%$ in relation to the earliest sowing date (Figure S5).

Many studies show that photoperiodism is more important in soybeans than in other crops. Varieties intended for cultivation in southern latitudes tend to respond more strongly to shorter days than varieties adapted to the northern region. For this reason, southern genotypes bloom too late in the north, and northern ones bloom too early in the south $[9,30]$.

The relation between generative and vegetative development against the background of the changing day length for the latitude of Wrocław is shown in Figure S6.

Gaynor et al. (2012) [31] showed, under the conditions of New South Wales, large differences in the length of vegetative development, which were shaped by the genetic factor, the sowing date, and the system of climatic conditions during the research. Higher temperatures accelerated flowering, and the extended day delayed it. The flowering of the earliest genotypes was not dependent on the photoperiodic response, and the duration of flowering, which was shaped by the sowing date and the year of study, was influenced by temperature. On the other hand, flowering of later genotypes was more dependent on the photoperiod response, while flowering occurred later and was more sensitive to the sowing date. Because the soybean is a plant sensitive to the photoperiod, and the number of hours during the day is determined according to the latitude, it is important to properly choose the sowing date in relation to the place of cultivation [28].

The optimal sowing date is one of the most important and least expensive agronomic practices that can affect soybean yield [32].

All examined factors significantly affected obtained seed yield of soybean. The interaction between SxC and SxCxY had no significant impact on seed yield (Table 5).

Table 5. Three-way analysis of variance (ANOVA) for the yield of soybeans seeds in different years, sowing dates, and cultivars.

\begin{tabular}{|c|c|c|c|c|c|}
\hline Specification & SS & Df & MS & F-Ratio & $p$-Value \\
\hline \multicolumn{6}{|c|}{ For factors and years } \\
\hline Sowing dates & 1.540 & 2 & 0.770 & 33.36 & $<0.05$ \\
\hline Cultivars & 0.215 & 1 & 0.215 & 6.24 & $<0.05$ \\
\hline Years & 16.52 & 3 & 5.506 & 238.59 & $<0.05$ \\
\hline \multicolumn{6}{|c|}{ For interactions } \\
\hline Sowing dates $\times$ Cultivars & 0.061 & 2 & 0.031 & 0.419 & 0.419 \\
\hline Sowing date $\times$ Years & 1.257 & 6 & 0.209 & 9.07 & $<0.05$ \\
\hline Cultivars $\times$ Years & 0.924 & 3 & 0.308 & 8.95 & $<0.05$ \\
\hline Sowing dates $\times$ Cultivars $\times$ Years & 0.080 & 6 & 0.013 & 0.013 & 0.881 \\
\hline Residual & 2.183 & 72 & 0.030 & & \\
\hline Total & 22.78 & 95 & 0.240 & & \\
\hline
\end{tabular}

SS—sum of squares; Df—-degrees of freedom; MS—-mean squares; ANOVA for the data significance was assessed at $p$ value $\leq 0.05$ (three-way ANOVA).

The most favorable for high soybean yield was the earliest date (I) and the date delayed by 10 days in relation to the earliest (II) (Table S2) when the greatest sum of the day length and the sum of mean daily temperatures were noted (Table 4). Similar results as our own were obtained by Bateman et al. (2020) [33]. According to Bateman et al. (2020) [33], soybean yield decreased $26.7 \mathrm{~kg} \mathrm{ha}^{-1}$ per day when soybean was planted after 
20 April. This research shows that the optimum planting dates for soybean in Mississippi are between 10 April and 1 May. In regions without additional irrigation or limited rainfall, planting dates can have a greater effect on soybean yield potential [34]. For soybeans cultivated in the United States in Maryland, Chen and Wiatrak (2010) [24] suggest that May planting dates can support greater yield potential by extending duration of development stages and avoiding cooler temperatures during seed-fill. Additionally, Mourtzinis et al. (2015) [35] claims that postponing the soybean sowing date to late May or early June in the upper Midwest of the United States can cause significant yield losses. In the study of Kundu et al. (2016) [36], delayed sowing date contributed to lower yield because of the loss of suitable time for the growth, similarly to our research. The same results as in our study were derived by Kumagai and Takahasi (2020) [32]. Sowing dates had significant effect on seed yield but were not significantly affected by the interaction of year-sowing date-cultivar.

Lissabon produced greater soybean yield than Merlin. The year of 2016 was the most favorable for soybean yield (Table S2). Cultivar Merlin is regarded as the most productive cultivar in Germany and Poland [37,38]. Additionally, Wenda-Piesk and Kazek (2016) [39] indicate the Merlin cultivar as high-yielding, especially when cultivated on soil of wheat class. In the research of Jarecki and Bobrecko-Jamro (2011) [25], among tested cultivars (Aldana, Lissabon, and Merlin), the cultivar Aldana produced the lowest seed yield, which was confirmed in years of research, and Lissabon and Merlin yielded similarly. Our research results differ from those mentioned above.

According to Chen and Wiatrak (2010) [24] and Salmeron et al. (2015) [40], there is a tendency of seed yield increase in the USA by optimizing the sowing date with the cultivar maturity group (MG). Delayed sowing date is the reason of shortened vegetative and reproductive phases to maturity for soybean cultivars: MG 1.4 and MG 2.4 [41]. However, changes in seeds yield with delayed sowing date are not the same for full season and short season cultivars [42]. Research conducted in Serbia showed that delaying the sowing date by 20 days (from the beginning of April to the middle of the second week of this month) resulted in a significant decrease in soybean seed yield [43]. On other hand, the delay in sowing date favors maturation and yield of late soybean varieties in the climatic conditions of south-eastern France [44]. Jarecki and Bobrecka-Jamro (2021) [25] showed that the soybean yield in eastern Poland was not dependent on the sowing date, which contradicts the conclusions presented in the paper.

The highest seed yield was obtained in 2016 in the earliest (I) and the delayed by 10 dates in relation to the earliest (II) dates of sowing in both tested cultivars, while the lowest was in Merlin cultivar in 20 days delayed sowing date (III) in 2017. The highest differences (SD) between seed yields were found in Merlin cultivar in the third sowing date in 2016 (Table 6).

Analyzing the interaction of sowing date and years, it can be stated that the highest yield was obtained in the earliest (I) and the 10 days delayed (II) sowing date in 2016, and the lowest was in 2017, when the sowing was 20 days delayed in relation to the first date (III) (Figure S7).

The yield of seeds from tested cultivars varied in the years of research. The highest seed yield was observed in both cultivars in 2016, while the lowest was in 2017 in Merlin cultivar (Figure S8). In Jarecki and Bobrecka-Jamro (2021) [25] research, soybean yielded the lowest in 2017 and the highest in 2018. Even the current Polish studies on the impact of sowing date on development and yield of soybean show different results, indicating a very strong dependence of the development and the yield of soybean on light and thermal conditions in the cultivation area.

Discussing the effect of sowing dates on soybean development and yield is a difficult topic because soybean varieties of different maturity are grown around the world in different latitudes and climatic conditions.

The cited results indicate a strong differentiation of the responses of soybean genotypes to delaying the sowing date depending on the climatic conditions of the growing area. 
Table 6. Effect of sowing date and cultivars on soybean seed yield $\left(\mathrm{Mg} \mathrm{ha}^{-1}\right)$ for 2016-2019-Wrocław $51^{\circ} 10^{\prime} \mathrm{N}, 17^{\circ} 06^{\prime} \mathrm{E}$ (south-western Poland).

\begin{tabular}{|c|c|c|c|c|}
\hline & Specification & & Mean & SE \\
\hline \multirow{3}{*}{2016} & I & $\begin{array}{l}\text { Lissabon } \\
\text { Merlin }\end{array}$ & $\begin{array}{l}3.60^{\mathrm{a}} \\
3.54^{\mathrm{a}}\end{array}$ & $\begin{array}{l} \pm 0.065 \\
\pm 0.089\end{array}$ \\
\hline & II & $\begin{array}{l}\text { Lissabon } \\
\text { Merlin }\end{array}$ & $\begin{array}{l}3.33^{a b c} \\
3.49^{a b}\end{array}$ & $\begin{array}{l} \pm 0.070 \\
\pm 0.102\end{array}$ \\
\hline & III & $\begin{array}{l}\text { Lissabon } \\
\text { Merlin }\end{array}$ & $\begin{array}{l}2.81^{\text {defg }} \\
3.04^{b c d}\end{array}$ & $\begin{array}{l} \pm 0.084 \\
\pm 0.153\end{array}$ \\
\hline \multirow{3}{*}{2017} & I & $\begin{array}{l}\text { Lissabon } \\
\text { Merlin }\end{array}$ & $\begin{array}{c}2.60^{\text {defgh }} \\
2.14^{\text {hij }}\end{array}$ & $\begin{array}{l} \pm 0.067 \\
\pm 0.061\end{array}$ \\
\hline & II & $\begin{array}{l}\text { Lissabon } \\
\text { Merlin }\end{array}$ & $\begin{array}{c}2.37 \text { ghi } \\
1.95^{\mathrm{ij}}\end{array}$ & $\begin{array}{l} \pm 0.102 \\
\pm 0.132\end{array}$ \\
\hline & III & $\begin{array}{l}\text { Lissabon } \\
\text { Merlin }\end{array}$ & $\begin{array}{c}2.15^{\text {hij }} \\
1.85^{j}\end{array}$ & $\begin{array}{l} \pm 0.105 \\
\pm 0.126\end{array}$ \\
\hline \multirow{3}{*}{2018} & I & $\begin{array}{l}\text { Lissabon } \\
\text { Merlin }\end{array}$ & $\begin{array}{l}2.35 \text { ghi } \\
2.40 \text { ghi }\end{array}$ & $\begin{array}{l} \pm 0.067 \\
\pm 0.102\end{array}$ \\
\hline & II & $\begin{array}{l}\text { Lissabon } \\
\text { Merlin }\end{array}$ & $\begin{array}{c}2.57^{\text {efgh }} \\
2.58^{\text {defgh }}\end{array}$ & $\begin{array}{l} \pm 0.067 \\
\pm 0.041\end{array}$ \\
\hline & III & $\begin{array}{l}\text { Lissabon } \\
\text { Merlin }\end{array}$ & $\begin{array}{l}2.43^{\text {fgh }} \\
2.50^{\text {efgh }}\end{array}$ & $\begin{array}{l} \pm 0.102 \\
\pm 0.065\end{array}$ \\
\hline \multirow{3}{*}{2019} & I & $\begin{array}{l}\text { Lissabon } \\
\text { Merlin }\end{array}$ & $\begin{array}{l}2.90^{\text {cdef }} \\
2.79 \text { defg }\end{array}$ & $\begin{array}{l} \pm 0.050 \\
\pm 0.093\end{array}$ \\
\hline & II & $\begin{array}{l}\text { Lissabon } \\
\text { Merlin }\end{array}$ & $\begin{array}{l}2.95^{\text {cde }} \\
2.72^{\text {defg }}\end{array}$ & $\begin{array}{l} \pm 0.047 \\
\pm 0.069\end{array}$ \\
\hline & III & $\begin{array}{c}\text { Lissabon } \\
\text { Merlin }\end{array}$ & $\begin{array}{l}2.67^{\text {defg }} \\
2.56^{\text {efgh }}\end{array}$ & $\begin{array}{l} \pm 0.065 \\
\pm 0.062\end{array}$ \\
\hline
\end{tabular}

Sowing dates: I-the earliest (16-21.04), II-delayed 10 days in relation to the earliest date (26.04-10.05), IIIdelayed 20 days in relation to the earliest (06-19.05); SE-standard error. Different letters indicate a significant difference (Tukey's multiple range test).

\section{Conclusions}

Adjusting the sowing date to the climatic conditions of the growing area is crucial for high yield of soybeans. It is necessary to breed genotypes adapted to the day length and the thermal conditions of the cultivation area, because these factors significantly modify the course and the duration of soybean development phases, influencing the quantity of seed yield. Seed yield showed significant differences among sowing date and tested cultivars over years of experiment. Significantly higher seed yield was observed in the earliest date of sowing as well in the date delayed by 10 days in relation to the earliest. The minimum seed yield was stated in the date delayed by 20 days of sowing. Therefore, in Lower Silesia (south-western Poland), it is recommended to sow soybeans in the second-third weeks of April and at the beginning of May. The variety with the higher seed yield was Lissabon.

More research is needed on the effects of day length and temperature on soybean seed yields, especially in countries at higher latitudes, so that soybean cultivation could be profitable and not involve the risk of reduced seed yield or immaturity of late cultivars.

Supplementary Materials: The following are available online at https:/ /www.mdpi.com/article/10 .3390 /agriculture11050413/s1, Figure S1: Relation between sowing date and the sum of day length during soybean development in reference to the 1st sowing date., Figure S2: Effect of sowing date on mean day length $[\mathrm{h}]$ during vegetative and generative development of soybean., Figure S3: Relation between sowing date and the sum of mean daily temperatures during soybean development in reference to the 1st sowing date., Figure S4: Effect of sowing date on mean daily temperature [ $\left.{ }^{\circ} \mathrm{C}\right]$ during vegetative and generative development of soybean., Figure S5: Sowing date and the relative length of development periods from emergence in reference to their length at the 1st sowing date., Figure S6: Influence of sowing date on the duration of growth stages in relation to changing day 
length on Wrocław latitude $\left(51^{\circ} 10^{\prime} \mathrm{N}\right)$., Figure S7: Effect of SxY interaction on soybean seed yields., Figure S8: Effect of CXY interaction on soybean seed yields., Table S1: Development of soybean cultivars (mean \pm SD for 2016-2019)-Wrocław $51^{\circ} 10^{\prime} \mathrm{N}, 17^{\circ} 06^{\prime} \mathrm{E}$ (south-western Poland)., Table S2: Soybean seed yield [Mg ha-1 ${ }^{-1}-W r o c ł a w ~ 51^{\circ} 10^{\prime} \mathrm{N}, 17^{\circ} 06^{\prime} \mathrm{E}$ (south-western Poland).

Author Contributions: Conceptualization: A.K., M.K. and M.S.-A.; methodology: A.K., M.K. and L.K.; investigation: M.S.-A., A.J.-R. and W.H.; formal analysis: L.K.; writing-original draft preparation: M.S.-A. and M.K.; writing-review and editing: M.S.-A., A.J.-R. and L.K.; visualization: W.H., A.J.-R. and M.S.-A.; supervising: A.K. All authors have read and agreed to the published version of the manuscript.

Funding: This research was financed from the multiannual program 2016-2020 by the Ministry of Agriculture and Rural Development titled "Increasing the use of domestic fodder protein for the production of high-quality animal products in the conditions of sustainable development". Resolution No. 222/2015 of the Council of Ministers of 15 December 2015.

Institutional Review Board Statement: Not applicable.

Informed Consent Statement: Not applicable.

Data Availability Statement: Not applicable.

Conflicts of Interest: The authors declare no conflict of interest.

\section{References}

1. FAO. Food and Agricultural Organization of United Nations. 2021. Available online: http://www.fao.org/faostat/en/\#data/QC (accessed on 12 March 2021).

2. Haegele, J.W.; Below, F.E.; The Six Secrets of Soybean Success. Improving Management Practices for High Yield Soybean Production. 2013. Available online: http:/ / cropphysiology.cropsci.illinois.edu/documents/2012\%20Six $\% 20$ Secrets $\% 20$ of $\% 20$ Soybean\%20Success\%20report.pdf (accessed on 12 March 2021).

3. Below, F.E.; Davidson, D.J.; Seebauer, J. Six Secrets Special Report Secrets of Soybean Success. 2019. Available online: http: / / cropphysiology.cropsci.illinois.edu/documents/SixSecrets_HandOut_2018.pdf (accessed on 10 March 2021).

4. Constable, G.A.; Rose, I.A. Variability of soybean phenology response to temperature, daylength and rate of change in daylength. Field Crop. Res. 1988, 18, 57-69. [CrossRef]

5. Câmara, G.M.S.; Sediyama, T.; Dourado-Neto, D.; Bernardes, M.S. Influence of photoperiod and air temperature on the growth, flowering and maturation of soybean (Glycine max (L.) Merrill). Sci. Agric. 1997, 54, 149-154. [CrossRef]

6. Wu, T.T.; Li, J.Y.; Wu, C.X.; Sun, S.; Mao, T.T.; Jiang, B.J.; Hou, W.S.; Han, T.F. Analysis of the independent- and interactive-photothermal effects on soybean flowering. J. Integr. Agric. 2015. [CrossRef]

7. Rockenbach, A.P.; Caron, B.O.; De Souza, V.Q.; Elli, E.F.; De Oliveira, D.M.; Monteiro, G.C. Estimated length of soybean phenological stages. Semin. Ciênc. Agrár. 2016, 37, 1871. [CrossRef]

8. Cober, E.R.; Voldeng, H.D. A new soybean maturity and photoperiod-sensitivity locus linked to E1 and T. Crop Sci. 2001, 41, 698-701. [CrossRef]

9. Heatherly, L.G.; Elmore, R.W. Managing Inputs for Peak Production. In Soybeans: Improvement, Production and Uses, 3rd ed.; Agronomy Monographs; Specht, J.E., Boerma, H.R., Eds.; ASA-CSSA-SSSA: Madison, WI, USA, 2004; Volume 16, pp. $451-536$.

10. Stein, H.H.; Berger, L.L.; Drackley, J.K.; Fahey, G.C., Jr.; Hernot, D.C.; Parsons, C.M. Nutritional properties and feeding values of soybeans and their co-products. In Soybeans, Chemistry, Production, Processing, and Utilization; Johnson, L.A., White, P.J., Galloway, R., Eds.; AOCS Press: Urbana, IL, USA, 2008; pp. 613-660.

11. Niwińska, B.; Witaszek, K.; Niedbała, G.; Pilarski, K. Seeds of n-GM Soybean Varieties Cultivated in Poland and Their Processing Products as High-Protein Feeds in Cattle Nutrition. Agriculture 2020, 10, 174. [CrossRef]

12. EUROSTAT. 2018. Available online: https:/ / ec.europa.eu/eurostat/en/web/products-eurostat-news/-/ddn-20190325-1 (accessed on 15 April 2021).

13. Dzwonkowski, W.; Rola, K.; Hanczakowska, E.; Niwińska, B.; Światkiewicz, S. Economic Aspects of Replacing GM Soybeans by Protein Feed Crops Grown in Poland; Institute of Agricultural and Food Economics-National Research Institute: Warsaw, Poland, 2016; ISBN 978-83-7658-656-4. (In Polish)

14. De Visser, C.L.M.; Schreuder, R.; Stoddard, F. The EU's dependency on soya bean import for the animal feed industry and potential for EU produced alternatives. OCL 2014, 21, D407. [CrossRef]

15. KZPRiRB 2020, Powierzchnia Upraw 2020 i 2019 Rzepak i Rośliny Bobowate. (In Polish). Available online: https:/ / www.kzprirb. pl (accessed on 14 April 2021).

16. Yamaguchi, N.; Kurosaki, H.; Kawasaki, M.; Sende, M.; Mioyshi, T. Early-Maturing and Chilling-Tolerant Soybean Lines Derived from Crosses between Japanese and Polish Cultivars. Plant Prod. Sci. 2015, 18, 234-239. [CrossRef]

17. Cober, E.R.; Morrison, M.J. Regulation of seed yield and agronomic characters by photoperiod sensitivity and growth habit genes in soybean. Theor. Appl. Genet. 2010, 120, 1005-1012. [CrossRef] 
18. IHAR Instytut Hodowli i Aklimatyzacji Roślin—Państwowy Instytut Badawczy (Plant Breeding and Acclimatization Institute). (In Polish). Available online: http:/ / pw.ihar.edu.pl/obszar-tematyczny-2/zadanie-2-6-wytworzenie-zrodel-genetycznych-dohodowli-odmian-soi-przydatnych-do-uprawy-w-roznych-warunkach-agro-klimatycznych-polski/ (accessed on 15 April 2021).

19. FAO. World Reference Base for Soil Resources 2014 International Soil Classification System; FAO: Rome, Italy, 2015; ISBN 9789251083697.

20. Kabała, C.; Charzyński, P.; Chodorowski, J.; Drewnik, M.; Glina, B.; Greinert, A.; Hulisz, P.; Jankowski, M.; Jonczak, J.; Łabaz, B.; et al. Polish soil classification, 6th edition-Principles, classification scheme and correlations. Soil Sci. Annu. 2019, 70, 71-97. [CrossRef]

21. Meier, U. Growth Stages of Mono- and Dicotyledonous Plants; JKI: Quedlinburg, Germany, 2001. [CrossRef]

22. Mourtzinis, S.; Specht, J.E.; Conley, S.P. Defining Optimal Soybean Sowing Dates across the US. Sci. Rep. 2019. [CrossRef] [PubMed]

23. Gaspar, A.P.; Conley, S.P. Responses of Canopy Reflectance, Light Interception, and Soybean Seed Yield to Replanting Suboptimal Stands. Crop Sci. 2015, 55, 377-385. [CrossRef]

24. Chen, G.; Wiatrak, P. Soybean development and yield are influenced by planting date and environmental conditions in the southeastern coastal plain, United States. Agron. J. 2010, 102, 1731-1737. [CrossRef]

25. Jarecki, W.; Bobrecka-Jamro, D. Effect of sowing date on the yield and seed quality of Soybean [Glycine max (L.) Merr.]. J. Elem. 2021, 26, 7-18. [CrossRef]

26. Setiyono, T.D.; Weiss, A.; Specht, J.; Bastidas, A.M.; Cassman, K.G.; Dobermann, A. Understanding and modeling the effect of temperature and daylength on soybean phenology under high-yield conditions. Field Crop. Res. 2007, 100, 257-271. [CrossRef]

27. Nico, M.; Miralles, D.J.; Kantolic, A.G. Natural post-flowering photoperiod and photoperiod sensitivity: Roles in yielddetermining processes in soybean. Field Crop. Res. 2019, 231, 141-152. [CrossRef]

28. Sediyama, T. Tecnologias de Produção e Usos da Soja; Mecenas Publishing: Londrina, Brazil, 2009; ISBN 9788589687089.

29. Rocha, R.S.; da Silva, J.A.L.; Neves, J.A.; Sediyama, T.; Teixeira, R.D.C. Desempenho agronômico de variedades e linhagens de soja em condições de baixa latitude em Teresina-PI. Rev. Ciênc. Agron. 2012. [CrossRef]

30. Zhang, L.X.; Kyei-Boahen, S.; Zhang, J.; Zhang, M.H.; Freeland, T.B.; Watson, C.E.; Liu, X. Modifications of Optimum Adaptation Zones for Soybean Maturity Groups in the USA. Crop Manag. 2007, 6. [CrossRef]

31. Gaynor, L.G.; Lawn, R.J.; James, A.T. Agronomic studies on irrigated soybean in southern New South Wales. I. Phenological adaptation of genotypes to sowing date. Crop Pasture Sci. 2011. [CrossRef]

32. Kumagahi, E.; Takahasi, T. Soybean (Glycine max (L.) Merr.) Yield Reduction due to Late Sowing as a Function of Radiation Interception and Use in a Cool Region of Northern Japan. Agronomy 2020, 10, 66. [CrossRef]

33. Bateman, N.; Catchot, A.; Gore, F.; Cook, D.; Musser, R.; Irby, T. Effects of Planting Date for Soybean Growth, Development, and Yield in the Southern USA. Agronomy 2020, 10, 596. [CrossRef]

34. Savoy, B.R.; Cothren, J.T.; Shumway, C.R. Early-season production systems utilizing indeterminate soybean. Agron. J. 1992, 84, 394-398. [CrossRef]

35. Mourtzinis, S.; Specht, J.E.; Lindsey, L.E.; Wiebold, W.J.; Ross, J.; Nafziger, E.D.; Kandel, H.J.; Mueller, N.; DeVillez, P.L.; Arriaga, F.J.; et al. Climate-induced reduction in US-wide soybean yields underpinned by region-and in-season-specific responses. Nat. Plants 2015, 1, 14026. [CrossRef] [PubMed]

36. Kundu, P.; Roy, T.S.; Khan, S.H.; Parvin, H.; Mazed, H.E.M.K. Effect of Sowing Date on Yield and Seed Quality of Soybean. J. Agric. Ecol. Res. Int. 2016, 9, 1-7. [CrossRef]

37. Zimmer, S.; Messmer, M.; Haase, T.; Piepho, H.-P.; Mindermann, A.; Schulz, H.; Habekuß, A.; Ordon, F.; Wilbois, K.-P.; Heß, J. Effects of soybean variety and Bradyrhizobium strains on yield, protein content and biological nitrogen fixation under cool growing conditions in Germany. Eur. J. Agron. 2016, 72, 38-46. [CrossRef]

38. Coskan, A.; Dogan, K. Symbiotic Nitrogen Fixation in Soybean. Soybean Physiology and Biochemistry. IntechOpen. 2011. Available online: https://www.intechopen.com/books/soybean-physiology-and-biochemistry/symbiotic-nitrogen-fixationin-soybean (accessed on 15 April 2021).

39. Wenda-Piesik, A.; Kazek, M. Productivity of early maturing cultivars of soybeans (Glycine max L. Merr) in north-western Poland. In Proceedings of the 14th ESA Congress, Edinburgh, UK, 5-9 September 2016; pp. 25-26.

40. Salmerón, M.; Gbur, E.E.; Bourland, F.M.; Golden, B.R.; Earnest, L.; Purcell, L.C. Soybean maturity group choices for maximizing light interception across planting dates in the U.S. Midsouth. Agron. J. 2015, 107, 2132-2142. [CrossRef]

41. Nleya, T.; Schutte, M.; Clay, D.; Reicks, G.; Maulker, N. Planting date, cultivar, seed treatment, and seeding rate effects on soybean growth and yield. Agroecosyst. Geosci. Environ. 2021, 3. [CrossRef]

42. Vossenkemper, J.P.; Nagziger, E.D.; Wessel, J.R.; Maughan, M.W.; Rupert, M.E.; Schmidt, J.P. Early planting, full-season cultivars, and seed treatments maximize soybean yield potential. Crop Forage Turfgrass Manag. 2016, 1, 1-9. [CrossRef]

43. Mandić, V.; Đorđević, S.; Đorđević, N.; Bijelić, Z.; Krnjaja, V.; Petričević, M.; Brankov, M. Genotype and sowing time effects on soybean yield and quality. Agriculture 2020, 10, 502. [CrossRef]

44. Maury, P.; Andrianasolo, F.N.; Alric, F.; Berger, M.; Beugniet, G.; Chambert, C.; Champolivier, L.; Doumenc, A.; Estragnat, A.; Gras, A.; et al. Le semis très précoce: Une stratégie agronomique pour améliorer les performances du soja en France? OCL 2015, 22, D503. [CrossRef] 